$\underline{\text { Review Article }}$

\title{
ARTHROBACTER AS BIOFACTORY OF THERAPEUTIC ENZYMES
}

\author{
SHABNAM, WAMIK AZMI* \\ Department of Biotechnology, Himachal Pradesh University, Summer Hill, Shimla, Himachal Pradesh, India \\ Email: wamikazmi@rediffmail.com
}

Received: 14 Mar 2018 Revised and Accepted: 04 Oct 2018

\begin{abstract}
Therapeutic enzymes are proteins which can be used to treat rare and deadly diseases. They represent a small but profitable market. Therapeutic enzymes are superior to non-enzymatic drugs owing to their high specificity toward the target and also their ability to multiple substrate conversion. They are essential for speeding up all the metabolic processes and many a life-supporting chemical inter-conversions. Actinomycetes including Arthrobacter form an enormous reservoir of secondary metabolites and enzymes. The characterization of L-asparaginase, $\beta$-glucosidase, urate oxidase, methionine $\gamma$-lyase, acetyl cholinesterase, and arginase activities from actinomycetes Arthrobacter clearly demonstrate the potential of Arthrobacter as potent producer of therapeutic enzymes. These metabolic enzymes can be used either separately or in combination with other therapies for the treatment of several diseases such as leukemia, gout, asthma, and neurological disorders. The objective of this review is to compile the information on the application of therapeutic enzymes produced by Arthrobacter and their future prospects as drugs.
\end{abstract}

Keywords: Actinomycetes, Arthrobacter, Diseases, Therapeutic enzymes, Therapies

(C) 2018 The Authors. Published by Innovare Academic Sciences Pvt Ltd. This is an open-access article under the CC BY license (http://creativecommons.org/licenses/by/4.0/) DOI: http://dx.doi.org/10.22159/ijpps.2018v10i11.25933

\section{INTRODUCTION}

Among new drug substances, the use of proteins as pharmaceuticals is steadily increasing [1]. Microbes contribute to the production of the majority of commercially important bioactive compounds. The microorganisms have proved to be very efficient and economical source of therapeutic enzyme and are preferred over plants and animals, owing to their economic cultivation, stability, flexibility in process modification and optimization. All these characteristics facilitate the large-scale microbial production of enzymes [2]. Actinomycetes are widely distributed in the earth's ecosystem and are the most potent resource of biotechnological and pharmaceutical studies [3]. Previous studies conducted on actinomycetes were directed mainly on antibiotic production, only a few reports citing the potential of actinomycetes for the production of enzymes have been listed.

Microbial isolates belonging to genus Arthrobacter are a notable source for the production of therapeutic enzymes. The Arthrobacter genus constituted by Conn and Dimmick [4] consisting of more than 84 species exhibiting high $\mathrm{G}+\mathrm{C}$ content ranging from 59 to $66 \mathrm{~mol} \%$ [5]. The species of Arthrobacter genus are most prevalent amongst soil bacteria. The member species of genus Arthrobacter are Grampositive and obligate aerobes. They form a soft and smooth colony which is yellow to white in coloration $[6,7]$. They undergo rodcoccus growth cycle. However, some members of the genus are spherical in shape, occurring in pairs and tetrad similar to A. agilis [4]. A. atrocyaneus, A. citreus and A. simplex exhibit mobility initially, but become non-motile after attaining coccoid morphology [8]. The Arthrobacter genus is metabolically versatile producing many different enzymes and also resilient to undesirable environmental conditions. They are prolific sources of medically important enzymes with multifarious applications. They are also used in the bioremediation of groundwater contaminated with pesticides and herbicides [9]. Arthrobacter sp. genera serve as bioindicators of contaminated habitats and also act as agents for bioremediation of contaminants, mostly by facilitating the synthesis of proteins for cellular survival [10].

The application of microbial enzymes as the drug is an important aspect of the present-day pharmaceutical industry. A very high degree of purity is needed for therapeutic enzyme preparations. Usually, enzymes with low $K_{\mathrm{m}}$ and high $V_{\max }$ value are selected because of their maximal efficiency even at a very low concentration of enzyme and substrate. Thus, the selection of sources for the production of such enzymes is crucial [2]. A number of medically useful enzymes have been reported from genus Arthrobacter. Subsequently, isolates of Arthrobacter genus gained much attention of researchers. Taking into consideration the importance of therapeutic enzymes, the enzymes produced by the members of the genus Arthrobacter can be classified into three categories. These are pharmaceutical enzymes where the protein directly acts as the therapeutic agent, prodrug-activating enzymes where the protein indirectly results in a clinical effect and diagnostic enzymes where the protein is highly selective and specific to target and provide merit over available analytical methods (fig. 1). The information on the application of medically important enzymes produced by the members of the genus Arthrobacter is compiled in this review to explore the future prospects of these therapeutic enzymes as drugs.

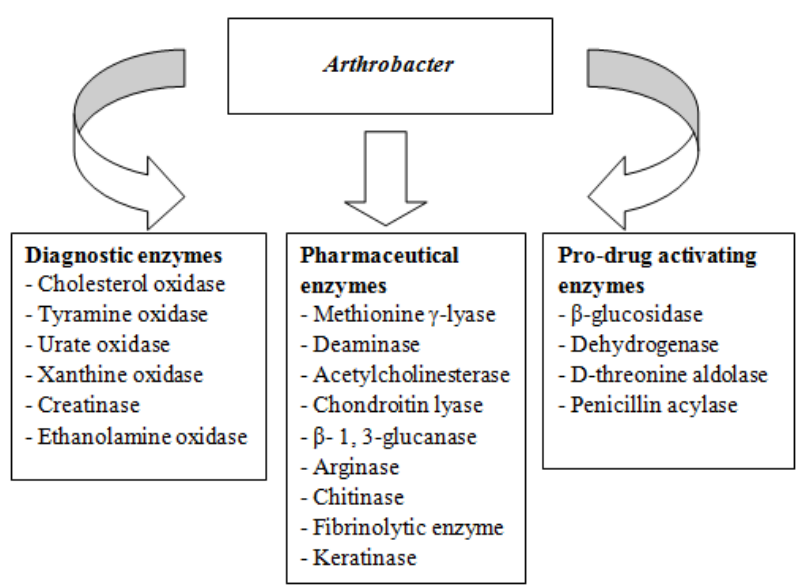

Fig. 1: Schematic illustration of different therapeutic enzymes reported from Arthrobacter sp

Therapeutic enzymes producing Arthrobacter sp. of terrestrial origin

Soil represents a promising habitat for discovering and isolating new natural products, and only $<1 \%$ of soil bacterial species are 
currently known [11]. The Arthrobacter genus is an indigenous flora of soil and usually consists of an important section of the rhizosphere microflora. A key characteristic of Arthrobacter is their nutritional versatility with simple nutritional needs together with the ability to exploit a number of compounds as a source of carbon and nitrogen. The main features of Arthrobacter held responsible for their prominent ecological presence in arid soils are the minimum growth rate, the rapid decrease in endogenous metabolism, the accumulation of a considerable amount of reserve material, the high resistance to desiccation in soil, the small spheroidal shape of cells and the long survival times during starvation [12].

Cold-active $\beta$-galactosidase producing Arthrobacter sp. SB has been reported from Antarctic soil samples. This enzyme has an optimal growth temperature of $15-20^{\circ} \mathrm{C}$ at $\mathrm{pH} 7.0$ and a subunit molecular mass of $114 \mathrm{kDa}$. It is specific for lactose and not inhibited by calcium or sodium ions present in milk [13]. All these properties render it useful for the production of low-lactose milk for lactose intolerant people and can also be used as a supplement along with amylase, lipase, and protease in lactose intolerant people. Other species, namely A. psychrolactophilus F2, Arthrobacter sp. 32cB, Arthrobacter sp. 20B and Arthrobacter sp. ON14 were also reported for production of cold-active $\beta$-galactosidase [14]. Arthrobacter sp. SD5 isolated from oil containing soil samples with lipase activity possess pharmaceutical applications. They studied medium composition and culture conditions for improved production of lipase. Olive oil $(2.5 \%)$ as a carbon source, peptone $(1.0 \%)$ as a nitrogen source and Tween-80 $(0.2 \%)$ as biosurfactant gave the optimal lipase yield [15]. Arthrobacter sp. strain PF01 obtained from Penguin feathers collected from Elephant Island, Antartica was found to produce keratinase with potential medical use [16]. Isolated a bacterium from ornithogenic soil and feather fragments with keratinolytic activity in low temperature $\left(5^{\circ} \mathrm{C}\right)$. Arthrobacter sp. strain PF1 was identified based on morphological and biochemical tests and 16S rRNA sequencing. We bacterium presented optimum growth at 4 and $25^{\circ} \mathrm{C}$, but not at $37^{\circ} \mathrm{C}$. Proteolytic activity was observed at 4 and $25^{\circ} \mathrm{C}$ in $\mathrm{pH} 7$ an

\section{Therapeutic enzyme producing Arthrobacter sp. of aquatic origin}

Over billions of years, the ocean has been regarded as the origin of life on the Earth. Thereby marine microbial enzymes can offer novel biocatalyst with extraordinary properties. The best marine source of bacteria is sediment and also reported from water, sand, rocks, marine plants, mangrove sediment, and deep sediment. The psychrotrophic bacterium Arthrobacter sp. 32c isolated from Antarctic Ocean reported to produce cold-adapted $\beta$-Dgalactosidase. The enzyme is active at $4-8{ }^{\circ} \mathrm{C}$ and of molecular weight of $195 \mathrm{kDa}$ and $75.9 \mathrm{kDa}$ for native protein and monomer subunit respectively [17]. The lactose intolerance person is not able to metabolise lactose due to a congenital deficiency of the enzyme $\beta$ galactosidase [18]. The $\beta$-galactosidase enzyme can be used to treat lactose intolerance. The bacterium $A$. oxydans producing dextranase was isolated from sea mud samples. This dextranase was reported for removal of dental plague and to treat dental caries [19].

An Arthrobacter sp. strain MAT3885 efficiently degrading chondroitin sulfate was isolated from marine environments. The optimum activity of chondroitin sulphate lyase was at $\mathrm{pH} 5.5-7.5$ and $40^{\circ} \mathrm{C}$, with $10 \mathrm{~min}$ of reaction time. The native enzyme was found to be a monomer [20]. It has been exposed analytically that chondroitin lyases inhibit melanoma invasion, proliferation, angiogenesis and to treat invertebral disc protrusion. It fosters the reclamation of axons of the central nervous system after injury [21]. The bacterium A. ilicis isolated from the marine sponge Spirastrella sp. produces extracellular serine-type acetylcholinesterase. The maximum activity of acetyl cholinesterase was found at $\mathrm{pH} 8.0$ and $45^{\circ} \mathrm{C}$ [22]. Arthrobacter sp. strain TAD20, a chitinolytic organism, was isolated from the sea bottom along the Antarctic ice shell. The bacterium secretes two major chitinases, ChiA and ChiB in response to chitin induction [23]. These chitinases exhibit medical functions like elicitor action and anti-tumor activity and to treat human diseases like asthma [24].

\section{Production of enzymes with biomedical applications by Arthrobacter}

The major therapeutic enzymes produced by Arthrobacter along with their applications have been presented in table 1.
L-asparaginase an important therapeutic enzyme belongs to amidase group. It accounts for about $40 \%$ of the global total enzyme sale. It is engrossed for the treatment of childhood acute lymphoblastic leukemia [25]. Its antileukemic effect work on the fact that tumor cells are incapable of synthesizing L-asparagine due to lack of aspartate-ammonia ligase activity. Administration of asparaginase depletes free exogenous L-asparagine thus left tumor cells in a state of fatal starvation [2].

Urate oxidase is an effective curative agent in gout treatment and act as a therapeutic drug to regulate uric acid levels. Urate oxidase was also used as a reagent to monitor uric acid levels in body fluids [26]. Elitek ${ }^{\mathrm{TM}}$ is commercially available intravenous dosage form of urate oxidase, which not only resolves the deposition of newly synthesized urate but also eliminates the long-standing tissue deposits [27, 28].

$\boldsymbol{\beta}$-glucosidase obtained from A. chlorophenolicus catalyzes efficient biotransformation of major ginsenosides to highly active minor ginsenosides like $\mathrm{F}_{2}, \mathrm{Rh}_{1}, \mathrm{~F}_{1}$, etc. These minor ginsenosides show highly significant pharmacological activities including anti-fatigue, anti-inflammation, anti-neoplastic, anti-fatigue, anti-oxidant and anti-diabetic effects. The enzymatic transformation on these compounds is advantageous as it results in fewer byproducts, better environmental protection and higher stereo-specificity [29].

Methionine $\boldsymbol{\gamma}$-lyase (MGL) is used as a drug target for contagious ailments evoked by parasitic protozoa and anaerobic periodontal bacteria. Recombinant MGL also administered to cause a decline in the concentration of methionine essential for the growth of cancer cells. MGL degrades sulphur containing amino acids to $\alpha$-keto acids, ammonia and volatile thiols [30].

Acetylcholinesterase is mainly found at neuromuscular junctions where it serves to terminate synaptic transmission by hydrolyzing acetylcholine to inactive components namely choline and acetic acid. It is necessary for the conduction of impulses along the nerve and muscle fibers. It is used as a vaccine against Dictyocaulus viviparous and as a pretreatment drug in organophosphorus poisoning [22]. It is considered to be an important neurotransmitter in the regulation of cognitive function [31]. This enzyme regulates the acetylcholine levels, an anti-inflammatory molecule associated with the inflammatory response during parasitic diseases [32].

Chondroitin lyase obtained from Arthrobacter sp. MAT3885 is effective in enhancing the regeneration of the central nervous system after injury and also help in improving keloid pathology. It is a chondroitin sulfate degrading enzyme results in production of chondroitin sulfate oligo or disaccharides which have a broad biological activity like in symptomatic treatment of osteoarthritis, known for its anti-inflammatory action, anti-oxidant activity and potent 2, 2-diphenyl-1-picrylhydrazyl (DPPH) scavenging activity [20].

Dextranase is known to prevent dental caries and repress dental plague. Dextranase obtained from Arthrobacter sp. strain B7 hydrolyzed dextran and glucan from the dental plague. Dextranase works efficiently at temperatures of about $37^{\circ} \mathrm{C}$ and are widely used in medical and dental industries. It is used in oral care products like toothpaste and mouthwash for effective dental caries prevention. It is also used in the manufacturing of blood substitutes [33, 34, 35].

Arginase obtained from Arthrobacter sp. KUJ 8602 catalyses the hydrolysis of L-arginine. It involves in nutritional starvation therapy for treatment of human hepatocellular carcinoma, prostate cancer, and melanoma. In addition to anticancer activity, it was proved to be effective in the treatment of acute neurological disorders, rheumatoid arthritis and allergic asthma [36].

Inulase II Arthrobacter sp. H65-7 produces the enzyme inulase II that converts inulin into difructose anhydride (DFA). DFA is a promising nutrient for fighting osteoporosis because it helps absorption of calcium in the intestines [37, 38].

Hyaluronate lyase was obtained by cultivating A. globiformis strain A152. The optimum $\mathrm{pH}$ and temperature values for hyaluronate lyase activity were $\mathrm{pH} 6.0$ and $42{ }^{\circ} \mathrm{C}$, respectively [39]. It has been 
successfully utilized in ophthalmic surgery and dermatosurgery. It has been applied as a local adjuvant to expand the diffusion capacity of local anesthetics, thus enhancing the analgesic efficacy and the anesthetized area, especially in the first few minutes following injection, mitigating intra and postoperative pain [40].

Cyclodextrin glycosyltransferase (CGTase) was obtained from $A$. mysorens isolated from paddy field soil. CGTase catalyzes cyclisation of $\alpha$-1, 4-glucans to produce cyclodextrins. Cyclodextrins are carrier molecules useful in pharmaceuticals for preparation of immediate release oral dosage forms. The molecular weight of the purified protein as determined by SDS-PAGE was $75 \mathrm{kDa}$; purified CGTase was thermostable and stable over a wide $\mathrm{pH}$ range. Dissolution studies on $\beta$-cyclodextrin-Irbesartan complex revealed that $\beta$-CDs form was useful in preparing immediate release oral dosage forms of the drug [41].

Table 1: Major therapeutic enzymes produced by Arthrobacter

\begin{tabular}{|c|c|c|c|c|}
\hline S. No. & Enzymes & Microorganisms & Applications & Reference \\
\hline 1 & Acetylcholinesterase & A. ilicis & $\begin{array}{l}\text { Used as a pretreatment drug in organophosphorus poisoning and as } \\
\text { a vaccine against Dictyocaulus viviparous }\end{array}$ & 22 \\
\hline 2 & Amine transaminase & Arthrobacter sp. KNK168 & Synthesis of sitagliptin and medicine for type- 2 diabetes & 42 \\
\hline 3 & Arginase & $\begin{array}{l}\text { Arthrobacter sp. KUJ } \\
8602\end{array}$ & Anticancer activity & 36 \\
\hline 4 & Chitinase & Arthrobacter sp. & Antifungal agent & 43 \\
\hline 5 & Cholesterol oxidase & A. simplex U-S 3011 & Diagnosis of arteriosclerosis and determination of serum cholesterol & 44 \\
\hline 6 & Chondroitin lyase & $\begin{array}{l}\text { Arthrobacter sp. } \\
\text { MAT3885 }\end{array}$ & $\begin{array}{l}\text { Effective against keloid pathology and in the regeneration of central } \\
\text { nervous system after injury }\end{array}$ & 20 \\
\hline 7 & Creatinase & A. nicotianae 23710 & Application in clinical diagnosis of renal function & 45 \\
\hline 8 & $\begin{array}{l}\text { Cyclodextrin } \\
\text { glycosyltransferase }\end{array}$ & A. mysorens & $\begin{array}{l}\text { Production of } \beta \text {-cyclodextrin useful in preparing immediate release } \\
\text { oral dosage forms }\end{array}$ & 41 \\
\hline 9 & Deaminase & A. oxydans & Used in anticancer and antibacterial therapies & 46 \\
\hline 10 & Dehydrogenase & A. simplex 156 & Steroid drug biotransformation & 47 \\
\hline 11 & Dextranase & Arthrobacter sp. & Dental caries-preventing agent & 34 \\
\hline 12 & D-threonine aldolase & Arthrobacter sp. DK-38 & Production of bioactive molecules & 48 \\
\hline 13 & Ethanolamine oxidase & Arthrobacter sp. & Detection of phosphatidylethanolamine levels in serum & 49 \\
\hline 14 & Fibrinolytic enzyme FA-I & $\begin{array}{l}\text { A. aurescens strain } D R- \\
536\end{array}$ & Used as a thrombolysis agent & 50 \\
\hline 15 & Hyaluronate lyase & A. globiformis A152 & Used in ophthalmic surgery and dermatosurgery & 39,40 \\
\hline 16 & Keratinase & $\begin{array}{l}\text { Arthrobacter sp. strain } \\
\text { PF01 }\end{array}$ & Transmissible spongiform encephalopathies treatment & 16,51 \\
\hline 17 & L-arabinose isomerase & Arthrobacter sp. & $\begin{array}{l}\text { Produce D-tagatose which acts as a drug for anti-diabetic and } \\
\text { obesity control }\end{array}$ & 52 \\
\hline 18 & L-asparaginase & $\begin{array}{l}\text { A. kerguelensis VL- } \\
\text { RK_09 }\end{array}$ & Antileukemic effect & 25 \\
\hline 19 & Levanfructo-transferase & A. ureafaciens $\mathrm{K} 2032$ & $\begin{array}{l}\text { Production of DFA IV, which act as a low-calorie sweetener, inhibit } \\
\text { tooth decay, increase mineral absorption }\end{array}$ & 53 \\
\hline 20 & Lipase & $\begin{array}{l}\text { Arthrobacter sp. MTCC } \\
5125\end{array}$ & Resolution of chiral drugs and their intermediates & 54 \\
\hline 21 & Methionine $\gamma$-lyase & Arthrobacter sp. & Anti-parasitic and anti-cancer effects & 30 \\
\hline 22 & $\begin{array}{l}\mathrm{N} \text {-acylhomoserine } \\
\text { lactonase }\end{array}$ & $\begin{array}{l}\text { Arthrobacter sp. } \\
\text { IBN110 }\end{array}$ & Block quorum sensing & 55 \\
\hline 23 & Oxidoreductases & Arthrobacter sp. & Production of enantiomerically pure alcohols & 56 \\
\hline 24 & Penicillin acylase & A. viscosus ATCC15294 & Production of semisynthetic penicillins & 57 \\
\hline 25 & Protease & A. luteus & $\begin{array}{l}\text { Potential target for developing therapeutic agents against fatal } \\
\text { diseases such as cancer and AIDS }\end{array}$ & 58,59 \\
\hline 26 & $\begin{array}{l}\text { Serine hydroxymethyl- } \\
\text { transferase }\end{array}$ & Arthrobacter sp. & $\begin{array}{l}\text { Produce L-serine which is used to treat hereditary sensory, } \\
\text { autonomic neuropathy type } 1\end{array}$ & 60,61 \\
\hline 26 & Tyramine oxidase & $\begin{array}{l}\text { Arthrobacter sp B- } \\
0813\end{array}$ & Diagnosis of Leucine aminopeptidase activity in serum & 62 \\
\hline 27 & Urate oxidase & $\begin{array}{l}\text { A. globiformis FERM } \\
\text { BP-360 }\end{array}$ & Gout treatment and detection of uric acid in serum & 63 \\
\hline 28 & Xanthine oxidase & Arthrobacter sp. & $\begin{array}{l}\text { Used in amperometric biosensors for detection of xanthine and } \\
\text { hypoxanthine }\end{array}$ & 64 \\
\hline 29 & $\beta$-1, 3-glucanase & Recombinant $A$. luteus & Paratransgenic control of Chagas disease & 65 \\
\hline 30 & $\beta$-galactosidase & A. psychrolactophilus & Production of low lactose milk for treatment of hypolactasia & 66 \\
\hline 31 & $\beta$-glucosidase & A. chlorophenolicus & $\begin{array}{l}\text { Produce active minor ginsenosides having anti-neoplastic, anti- } \\
\text { fatigue, anti-oxidant and anti-diabetic effects }\end{array}$ & 29 \\
\hline
\end{tabular}

\section{CONCLUSION}

The member species of Arthrobacter genus have evolved as a group with vast metabolic and genomic diversity. Attempts should be aimed to explore the potential of Arthrobacter sp. as a source to produce novel therapeutic enzymes. The results of research on the use of Arthrobacter group for the production of therapeutic enzymes targeting various diseases have been presented. Although, symbolic progress in the discovery of different medically important enzymes has been conducted, but their large-scale commercial production is yet to be worked out. Purification is the primary step in the processing of therapeutic enzymes. Successful reports on medically important enzymes from terrestrial and aquatic Arthrobacter are available, but their commercial production conditions are yet to be investigated. In order to generate therapeutic enzymes as commercial products, different biosynthetic pathways need to be analyzed, then respective genes should be metabolically engineered, cloned into the desired host and bioprocess parameters have to be optimized.

\section{ACKNOWLEDGMENT}

Author Shabnam is thankful to the department of biotechnology (DBT), Govt. of India, for Senior Research Fellowship. 


\section{AUTHORS CONTRIBUTIONS}

All the author have contributed equally

\section{CONFLICTS OF INTERESTS}

The authors have declared that no conflict of interest exists

\section{REFERENCES}

1. Sakarkar DM, Kshirsagar RV, Tadavi SA, Pawde PK. Tableting compression behaviour of enzyme trypsin-chymotrypsin. Int J Appl Pharm 2009;1:30-43.

2. Mane $P$, Tale V. Overview of microbial therapeutic enzymes. Int J Curr Microbiol Appl Sci 2015;4:17-26.

3. Bull AT. Microbial diversity and bioprospecting. ASM Press: Washington DC; 2004. p. 496.

4. Conn HJ, Dimmick I. Soil bacteria similar in morphology to Mycobacterium and Corynebacterium. J Bacteriol 1947;54:291-303.

5. Kiran S, Swarnkar MK, Pal M, Thakur R, Twari R, Singh AK, et al. Complete genome sequencing of protease-producing novel Arthrobacter sp. strain IHBB 11108 using PacBio single-molecule real-time sequencing technology. Genome Announc 2015;3:1-2.

6. Mullakhanbhai MF, Bhat JV. Morphogenesis in Arthrobacter species. Proc Ind Acad Sci 1967;65:231-7.

7. Holt JG, Krieg NR, Sneath PHA, Stanley JT, Williams ST. Bergey's manual of determinative bacteriology. 9th ed. Baltimore: Williams and Wilkins; 1994.

8. Stanlake GJ, Clark JB. Motility as a morphogenic character in the genus Arthrobacter. J Bacteriol 1976;127:1524-8.

9. Mongodin EF, Shapir N, Daugherty SC, DeBoy RT, Emerson JB, Shvartzbeyn A, et al. Secrets of soil survival revealed by the genome sequence of Arthrobacter aurescens TC1. PLoS Genet 2006;2:2094-106.

10. Chauhan A, Pathak A, Jaswal R, Edwards B, Chappell D, Ball C, et al. Physiological and comparative genomic analysis of Arthrobacter sp. SRS-W-1-2016 provides insights on niche adaptation for survival in uraniferous soils. Genes 2018;9:31-50.

11. Powthong P, Sripean A, Suntornthiticharoen P. Screening of active antimicrobial and biological enzymes of microbial isolated from soil in Thailand Pannapa. Asian J Pharma Clin Res 2017;10:73-8

12. Cacciari I, Lippi D. Arthrobacters: successful arid soil bacteria: a review. Arid Soil Res Rehabil 1987;1:1-30.

13. Coker JA, Brenchley JE. Protein engineering of a cold-activegalactosidase from Arthrobacter sp. SB to increase lactose hydrolysis reveals new sites affecting low-temperature activity. Extremophiles 2006;10:515-24.

14. Pawlak A, Wicka M, Krajewska E. $\beta$-galactosidases from a psychrotolerant Arthrobacter isolates and their potential use. Pi J 2013;3:42-6.

15. Peng R, Lin W. Optimization of lipase production from Arthrobacter sp. SD5. Adv Mater Res 2013;791-3:116-9.

16. Ferrareze PAG, Vailati VH, Petry MV, Brandelli A, Medina LFC. Characterization of antarctic keratinolytic Arthrobacter sp. Ann Act Rep 2015;11:68-70.

17. Hildebrandt $\mathrm{P}$, Wanarska $\mathrm{M}$, Kur J. A new cold-adapted $\beta$-Dgalactosidase from the antarctic Arthrobacter sp. 32c-gene cloning, overexpression, purification, and properties. BMC Microbiol 2009;9:151-60.

18. Huidrom S, Singh RK, Chaudhary V. Bacteriotherapy: a novel therapeutic approach. Int J Curr Pharma Res 2016;8:12-6.

19. Wang D, Lu M, Wang X, Jiao Y, Fang Y, Liu Z, et al. Improving stability of a novel dextran-degrading enzyme from marine Arthrobacter oxydans KQ11. Carbohydr Polym 2014;103:294-9.

20. Kale V, Friojonsson O, Jonsson JO, Kristinsson HG, Omarsdottir $\mathrm{S}$, Hreggviosson GO. Chondroitin lyase from a marine Arthrobacter sp. MAT3885 for the production of chondroitin sulfate disaccharides. Mar Biotechnol 2015;17:479-92.

21. Linhardt RJ, Avci FY, Toida T, Kim YS, Cygler M. CS lyases: structure, activity, and applications in analysis and the treatment of diseases. Adv Pharmacol 2006;53:187-215.

22. Mohapatra BR, Bapuji M. Characterization of acetylcholinesterase from Arthrobacter ilicis associated with the marine sponge Spirastrella sp. J Appl Microbiol 1998;84:393-8.
23. Lonhienne T, Mavromatis K, Vorgias CE, Buchon L, Gerday C, Bouriotis V. Cloning, sequences and characterization of two chitinase genes from the antarctic Arthrobacter sp. strain TAD20: isolation and partial characterization of the enzymes. J Bacteriol 2001;183:1773-9.

24. Hamid R, Khan MA, Ahmad M, Ahmad MM, Abdin MZ, Musarrat J, et al. Chitinases: an update. J Pharm Bio Allied Sci 2013;5:21-9.

25. Muvva V, Munaganti RK, Indupalli MD. Studies on optimization of L-asparaginase production by Arthrobacter kerguelensis VLRK_09 isolated from mango orchards. Int J Pharm Pharm Sci 2015;7:112-5.

26. El-Naggar NEA. Isolation, screening, and identification of actinobacteria with urate oxidase activity: statistical optimization of fermentation conditions for improved production of urate oxidase by Streptomyces rochei NEAE-25. Int J Pharmacol 2015;11:644-58.

27. Dwivedi H, Agrawal K, Saraf SA. Screening of urate oxidase producing microorganisms and urate oxidase estimation: a simple and novel approach. Int J Pharm Pharm Sci 2012;4:422-4.

28. Newcombe DS. Gout: basic science and clinical practice. Springer, Heidelberg; 2012. p. 356-7.

29. Park MK, Cui CH, Park SC, Park SK, Kim JK, Jung MS, et al. Characterization of recombinant $\beta$-glucosidase from Arthrobacter chlorophenolicus and biotransformation of ginsenosides $\mathrm{Rb}_{1}, \mathrm{Rb}_{2}$, Rc and Rd. J Microbiol 2014;52:399-406.

30. Sato D, Nozaki T. Methionine gamma-lyase: the unique reaction mechanism, physiological roles and therapeutic application against infectious diseases and cancers. IUBMB Life 2009;61:1019-28.

31. Sumithra M, Arunachalam G, Chitra V, Gowri K. Neuroprotective effect of Sargassum ilicifolium turner C. Agardh on acetylcholinesterase activity and attenuation of scopolamine-induced amnesia in rodents. Asian J Pharma Clin Res 2016;9:93-6.

32. Silva AD, Bottari NB, Carmo GM, Baldissera MD, Souza CF, Machado VS, et al. Chagas disease: modulation of the inflammatory response by acetylcholinesterase in hematological cells and brain tissue. Mol Cell Biochem 2018;438:59-65.

33. Baktir A, Zaini NC, Murdiyatmo U, Kuntaman. The potency of dextranase from Arthrobacter sp. strain B7 as dental plaque removal. Catatan Penelitian 2005;12:162-6.

34. Jiao YL, Wang SJ, Lv MS, Jiao BH, Li WJ, Fang YW, et al. Characterization of a marine-derived dextranase and its application to the prevention of dental caries. J Ind Microbiol Biotechnol 2014;41:17-26.

35. Ren W, Cai R, Yan W, Lyu M, Fang Y, Wang S. Purification and characterization of a biofilm-degradable dextranase from a marine bacterium. Mar Drugs 2018;16:51-67.

36. Unissa R, Sudhakar M, Reddy ASK. A review of biochemical and therapeutic aspects of arginase. Int J Life Sci Pharma Res 2014;4:72-97.

37. Yokota A, Hirayama S, Enomoto K, Miura Y, Takao S, Tomita F. Production of inulin fructotransferase (depolymerizing) by Arthrobacter sp. H65-7 and preparation of DFA III from inulin by the enzyme. J Ferment Bioeng 1991;72:258-61.

38. Tomita K, Shiomi T, Okuhara Y, Tamura A, Shigematsu N, Hara $\mathrm{H}$. Ingestion of difructose anhydride III enhances absorption and retention of calcium in healthy men. Biosci Biotechnol Biochem 2007;71:681-7.

39. Zhu C, Zhang J, Li L, Zhang J, Jiang Y, Shen Z, et al. Purification and characterization of hyaluronate lyase from Arthrobacter globiformis A152. Appl Biochem Biotechnol 2016;182:216-28.

40. Buhren BA, Schrumpf H, Hoff NP, Bolke E, Hilton S, Gerber PA. Hyaluronidase: from clinical applications to molecular and cellular mechanisms. Eur J Med Res 2016;21:5-11.

41. Rajesh Y, Narayanan K, Reddy MS, Bhaskar VK, Shenoy GG, Subrahmanyam VM, et al. Production of $\beta$-cyclodextrin from $\mathrm{pH}$ and thermostable cyclodextrin glycosyltransferase, obtained from Arthrobacter mysorens and its evaluation as a drug carrier for irbesartan. Curr Drug Delivery 2015;12:444-53.

42. Guan L, Ohtsuka J, Okai M, Miyakawa T, Mase T, Zhi Y, et al. A new target region for changing the substrate specificity of amine transaminases. Sci Rep 2015;5:1-11. 
43. Morrissey RF, Dugan EP, Koths JS. Chitinase production by an Arthrobacter sp. lysing cells of Fusarium roseum. Soil Biol Biochem 1976;8:23-8.

44. Kumari L, Shamsher KS. Cholesterol oxidase: role in the biotransformation of cholesterol. J Appl Biol Biotechnol 2015;3:53-65

45. Dai J, Zhang L, Kang Z, Chen J, Du G. High-level production of creatine amidinohydrolase from Arthrobacter nicotianae 23710 in Escherichia coli. Appl Biochem Biotechnol 2015;175:2564-73.

46. Medici R, Lewkowicz ES, Iribarren AM. Arthrobacter oxydans as a biocatalyst for purine deamination. FEMS Microbiol Lett 2008;289:20-6.

47. Zhang H, Tian Y, Wang J, Li Y, Wang H, Mao S, et al. Construction of engineered Arthrobacter simplex with improved performance for cortisone acetate biotransformation. Appl Microbiol Biotechnol 2013;97:9503-14.

48. Liu JQ, Odani M, Dairi T, Itoh N, Shimizu S, Yamada H. A new route to L-threo-3[4-(methylthio)phenylserine], a key intermediate for the synthesis of antibiotics: recombinant lowspecificity d-threonine aldolase-catalyzed stereospecific resolution. Appl Microbiol Biotechnol 1999;51:586-91.

49. Ota H, Tamezane H, Sasano Y, Hokazona E, Yasuda Y, Sakasewage S. Enzymatic characterization of an amine oxidase from Arthrobacter sp. used to measure phosphatidylethanolamine. Biosci Biotechnol Biochem 2008;72:2732-8.

50. Ming Z, Haihong H, GaoXue W. Optimization on fermentation of Arthrobacter aurescens strain DR-536 to secrete a novel fibrinolytic enzyme FA-I. J NWAFU Nat Sci Ed 2010;38:33-9.

51. Selvam K, Vishnupriya B. Biochemical and molecular characterization of microbial keratinase and its remarkable applications. Int J Pharm Biol Arch 2012;3:267-75.

52. Fu H, Wei Y, Zou Y, Li M, Wang F, Chen J, et al. Research progress on the actinomyces Arthrobacter. Adv Microbiol 2014;4:747-53.

53. Kim CH, Jang EK, Kim SH, Jang KH, Kang SA, Song KB, et al. Molecular cloning of levan fructotransferase gene from Arthrobacter ureafaciens $\mathrm{K} 2032$ and its expression in Escherichia coli for the production of difructose dianhydride IV. Lett Appl Microbiol 2005;40:228-34.

54. Chaubey A, Parshad R, Koul S, Taneja SC, Qazi GN. Arthrobacter sp. lipase immobilization for improvement in stability and enantioselectivity. Appl Microbiol Biotechnol 2006;73:598606.
55. Park SY, Lee SJ, Oh TK, Koo BT, Yum DY, Lee JK. AhlD, an N-acyl homoserine lactonase in Arthrobacter sp. and predicted homologues in other bacteria. J Microbiol 2003;149:1541-50.

56. Araujo LS, Kagohara E, Garcia TP, Pellizari VH, Andrade LH. Screening of microorganisms producing cold-active oxidoreductases to be applied in enantioselective alcohol oxidation. An Antarctic survey. Mar Drugs 2011;9:889-905.

57. Ohashi H, Katsuta Y, Hashizume T, Abe SN, Kajiura H, Hattori H, et al. Molecular cloning of the penicillin $\mathrm{G}$ acylase gene from Arthrobacter viscosus. Appl Environ Microbiol 1988;54:2603-7.

58. Rao MB, Tanksale AM, Ghatge MS, Deshpande VV. Molecular and biotechnological aspects of microbial proteases. Microbiol Mol Biol Rev 1998;62:597-635.

59. Adamitsch BF, Karner F, Hampel W. Proteolytic activity of a yeast cell wall lytic Arthrobacter species. Lett Appl Microbiol 2003;36:227-9.

60. Huang J, Chen L, Hu N, Jiang W, Wu G, Liu Z. Characterization of a novel serine hydroxymethyltransferase isolated from marine bacterium Arthrobacter sp. and its application on l-serine production. Ann Microbiol 2015;65:1689-98.

61. Garofalo K, Penno A, Schmidt BP, Lee HJ, Frosch MP, Eckardstein AV, et al. Oral L-serine supplementation reduces production of neurotoxic deoxysphingolipids in mice and humans with hereditary sensory, autonomic neuropathy type 1. J Clin Invest 2016;121:4735-45.

62. Yoshino E, Matsuura K, Misaki H. Process for the production of tyramine oxidase. US 4496655 A; 1985.

63. Suzuki K, Sakasegawa SI, Misaki H, Sugiyama M. Molecular cloning and expression of urate oxidase gene from Arthrobacter globiformis in Escherichia coli and characterization of the gene product. J Biosci Bioeng 2004; 98:153-8.

64. Xin Y, Yang H, Xia X, Zhang L, Zhang Y, Cheng C, et al. Expression, purification and partial characterization of a xanthine oxidase (XOD) in Arthrobacter sp. Process Biochem 2012;47:1539-44.

65. Jose C, Klein N, Wyss S, Fieck A, Hurwitz I, Durvasula R. Recombinant Arthrobacter $\beta$-1, 3-glucanase as a potential effector molecule for paratransgenic control of chagas disease. Parasites Vectors 2013;6:65-73.

66. Nakagawa T, Fujimoto Y, Ikehata R, Miyaji T, Tomizuka N. Purification and molecular characterization of cold-active $\beta$ galactosidase from Arthrobacter psychrolactophilus Strain F2. Appl Microbiol Biotechnol 2006;72:720-5. 